\title{
Spot-on Applicator
}

National Cancer Institute

\section{Source}

National Cancer Institute. Spot-on Applicator. NCI Thesaurus. Code C149943.

Device for administration by spot-on use. 